\title{
Nuclei and DNA-Binding Form of the Steroid Receptor Complex in the Liver and the Ventral Prostate of Rats
}

\author{
SHOGO ICHII AND NORIKo MURAKAMI
}

\author{
Division of Physiology, Institute of Steroid Research, Tottori \\ University School of Medicine, Yonago 683, Japan
}

\begin{abstract}
Synopsis
Repeated treatments of the liver cytosol prelabeled with ${ }^{3} \mathrm{H}$-dexamethasone with DNA-cellulose followed by treatments with purified liver nuclei enabled us to assess the amount of two forms of dexamethasone-receptor complex, one binds only to nuclei and the other binds to DNA and nuclei. The comparable amount of these two forms of the receptor complex was detected in the dexamethasone-labeled liver cytosol, while only one form which binds only to nuclei was found in the liver cytosol labeled with antiglucocorticoid, cortexolone. The significant amount of receptor complex which binds to DNA and nuclei was not present in the cytosol from the ventral prostate preincubated with ${ }^{3} \mathrm{H}$-dihydrotestosterone.
\end{abstract}

An unified hypothesis for early biochemical sequence of events in steroid hormone action has been proposed by O'Malley (1971) and the basic features of hormone action have been outlined. The nuclear translocation of steroid cytoplasmic receptor complexes seems to be an obligatory step in the action of steroid hormone but very few details of this process have been understood. A number of investigations have been performed to examine the nuclear binding sites of steroid-receptor complexes however, the physiologically specific binding sites do not seem to have been established. Recently, Buller et al. (1976) separated and purified two subunits of progesterone receptor in the chick oviduct, one of which binds preferentially to DNA and the other binds only to chromatin. From these observations, they proposed a view that the one subunit which binds to DNA could be an actual gene regulatory protein and the other subunit could specify where in chromatin the DNA-binding subunit is to localize (O'Malley et at. 1976). Two forms of the glucocorticoid-receptor complex, nuclear and DNA-binding forms, were also observed in hepatoma tissue culture cells (Simons, 1977) and in the rat liver (Hamana and Iwai, 1978).

In the present study, a series of experiments were performed on the binding to DNA and to nuclei of the dexamethasonereceptor complex in the liver and the dihydrotestosterone-receptor complex in the ventral prostate to examine whether or not the two subunit receptor hypothesis proposed by O'Malley et al. (1976) would be applicable to the action mechanism of steroid hormones in other tissues. 


\section{Materials and Methods}

\section{Animals and tissue preparations}

Livers and ventral prostates were obtained from male Wistar rats weighing 200 and $350 \mathrm{~g}$, respectively. To prepare the cytosol, tissues were homogenized in 3 volumes of buffer solution containing $10 \mathrm{~mm}$ Tris- $\mathrm{HCl}(\mathrm{pH} 7.4), 2 \mathrm{~mm}$ 2-mercaptoethanol and 0.5 mM EDTA (buffer A). The supernatant obtained after successive centrifugation of the homogenate at $600 \times g$ for $10 \mathrm{~min}, 8,000 \times g$ for $20 \mathrm{~min}$ and $100,000 \times g$ for $60 \mathrm{~min}$ was used as the cytosol. For preparation of nuclei, tissues were homogenized in 3 volumes of medium which consisted of $20 \mathrm{~mm}$ Tris- $\mathrm{HCl}(\mathrm{pH}$ 7.4), $2 \mathrm{mM} \mathrm{CaCl}_{2}, 1 \mathrm{mM} \mathrm{MgCl}$ and $250 \mathrm{~mm}$ sucrose (buffer B). The homogenate was centrifuged at $600 \times$ $g$ for $10 \mathrm{~min}$, pellets were resuspended in buffer B and resedimented by centrifugation at $100,000 \times g$ for $60 \mathrm{~min}$ through a cushion of $1.7 \mathrm{M}$ sucrose. The nuclear fraction was washed twice with buffer B before use.

\section{Preparation of steroid cytoplasmic receptor complex}

The liver cytosol was incubated in the presence

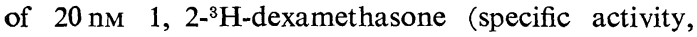
$24 \mathrm{Ci} / \mathrm{mmole}$ ) or $1,2{ }^{3} \mathrm{H}$-cortexolone (specific activity, $47 \mathrm{Ci} / \mathrm{mmole}$ ) at $0^{\circ} \mathrm{C}$ for $4 \mathrm{hr}$. Unbound steroid was removed by dextran-charcoal. The dihydrotestosterone-receptor complex in the cytosol from the ventral prostate was prepared in the similar manner using $1,2-{ }^{3} \mathrm{H}$-dihydrotestosterone (specific activity, $175 \mathrm{Ci}$ / mmole). All labeled steroids used in the present study were obtained from The Radiochemical Centre, Amersham, England.

Determination of the rate of the steroid-receptor complex binding to DNA and to nuclei

Preparation of DNA-cellulose and incubation of the steroid-receptor complex with DNA-cellulose were performed by the method which was essentially the same as described by Simons (1977) and Simons et al. (1976) using calf-thymus DNA (Type V, Sigma Chemical Co.) and cellulose powder (CF 11, Whatman Biochemicals). The content of DNA associated with cellulose used in the present study was 0.8$1.0 \mathrm{mg}$ per $\mathrm{ml}$. As shown in Fig. 1, it required approximately $30 \mathrm{~min}$ at $30^{\circ} \mathrm{C}$ for maximum binding of dexamethasone-recepter complex in buffer A; therefore, incubations were performed under these conditions in all DNA-binding experiments. The method used for the determination of the rate of steroidreceptor complex binding to nuclei was described previously (Ichii, et al., 1977). The purified nuclear fraction was suspended in buffer $B$ and incubated in the presence of the labeled receptor com- plex at $30^{\circ} \mathrm{C}$ for $15 \mathrm{~min}$. In both experiments, bound complexes to either DNA or nuclei were precipitated by brief centrifugation, washed twice with the respective buffer used for incubations and bound steroid was extracted with $3 \mathrm{~m} l$ of absolute ethanol. Ethanol fraction was transferred to a counting vial, evaporated down, and the radioactivity was determined.

\section{Analytical methods}

DNA and protein were determined by the methods of Burton (1956) and Lowry et al. (1951), respectively. The radioactivity of ${ }^{3} \mathrm{H}$ was determined in a liquid scintillation spectrometer using $10 \mathrm{ml}$ of toluene-based counting fluid.

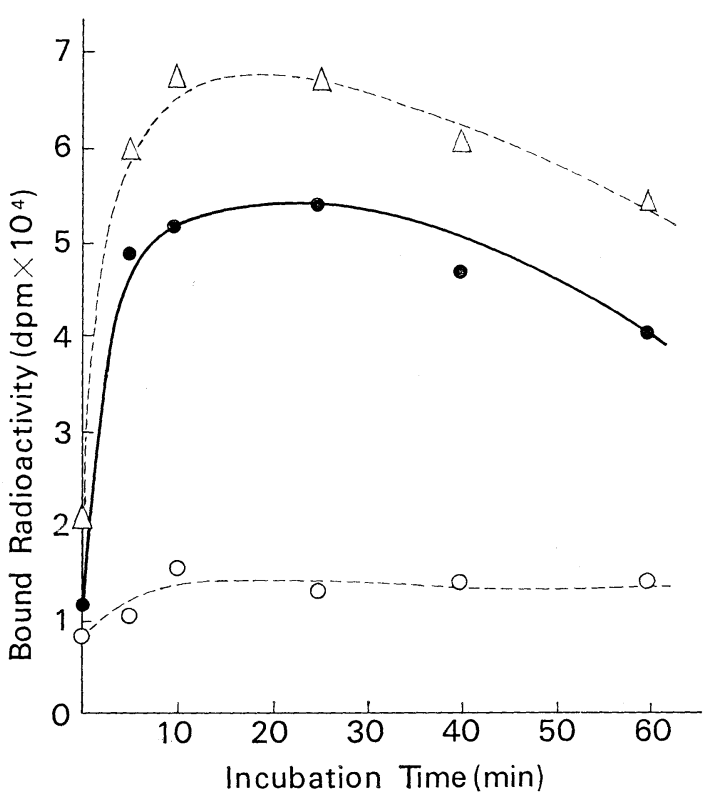

Fig. 1. Effect of the incubation time on the binding of ${ }^{3} \mathrm{H}$-dexamethasone receptor complex to DNAcellulose and cellulose. $4.3 \times 10^{5} \mathrm{dpm}$ of dexamethasone-receptor complex prepared as described in the text and $240 \mu \mathrm{g}$ of DNA-cellulose (as DNA) were used per tube. For the control incubations, the same amount of DNA-cellulose per tube was used after two treatments with hot buffer $A$ to remove associated DNA. Incubations were carried out at $30^{\circ} \mathrm{C}$ at indicated time intervals. Other details of the experimental conditions, see the text.

$\triangle$ Bound radioactivity to DNA-cellulose (1); 0 Bound radioactivity to DNA-removed DNA-cellulose ; Radioactivity specifically bound to DNA [(1)-(2)]. 


\section{Results}

To DNA-cellulose in a plastic tube, liver cytosol previously labeled with ${ }^{3} \mathrm{H}$-dexamethasone was poured and incubated at $30^{\circ} \mathrm{C}$ for $30 \mathrm{~min}$. After incubation, the mixture was briefly centrifuged, the supernatant was transferred to another tube containing fresh DNA-cellulose and incubated at $30^{\circ} \mathrm{C}$ for another $30 \mathrm{~min}$. Repeated treatments of the labeled cytosol with DNA-cellulose in this manner efficiently removed the receptor complex of DNA-binding form from the incubation mixture. After the 4th treatment, no significant binding to DNA-cellulose was observed (Fig. 2). Four DNA-cellulose sam-

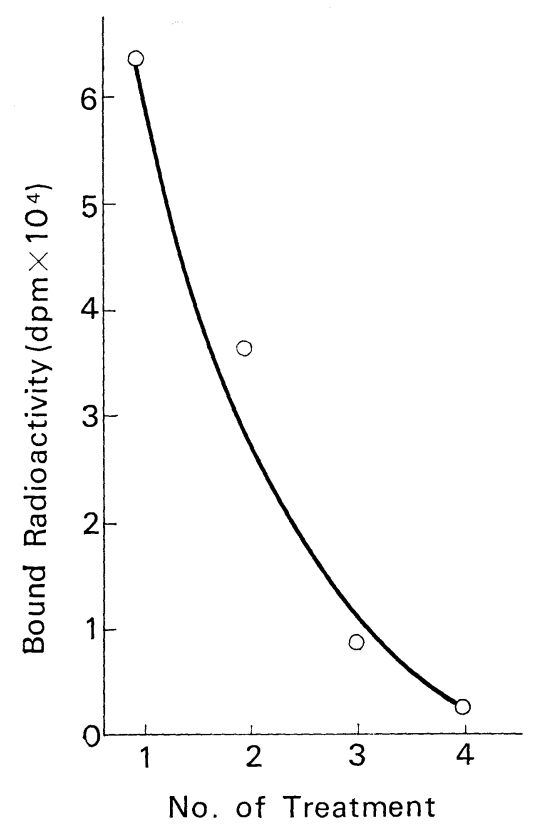

Fig. 2. Effect of multiple treatments with DNAcellulose on removal of dexamethasone-receptor complex which binds to DNA. $2.5 \times 10^{5} \mathrm{dpm}$ of dexamethasone-receptor complex was used for the starting material. $180 \mu \mathrm{g}$ of DNA-cellulose (as DNA) were used for each treatment. The DNAbound radioactivity was corrected for the radioactivity bound to cellulose non-specifically which was estimated in 4 parallel series of incubations using DNA-removed DNA-cellulose. Other details of the experimental conditions, see the text. ples used for treatment of the labeled cytosol were pooled, washed twice with buffer $A$ and bound radioactivity was determined after two extractions with ethanol. Under these conditions, the amount of the receptor complex which binds to DNA in the labeled cytosol was determined. Using purified nuclei instead of DNA-cellulose, the amount of the steroid receptor complex which binds to nuclei was determined by the similar procedures, except that the five consecutive treatments of labeled cytosol with fresh nuclei were required for the complete separation of the receptor complex of nuclear binding form (Fig. 3). When dexamethasone-labeled liver cytosol was treated with nuclei first, almost all the labeled

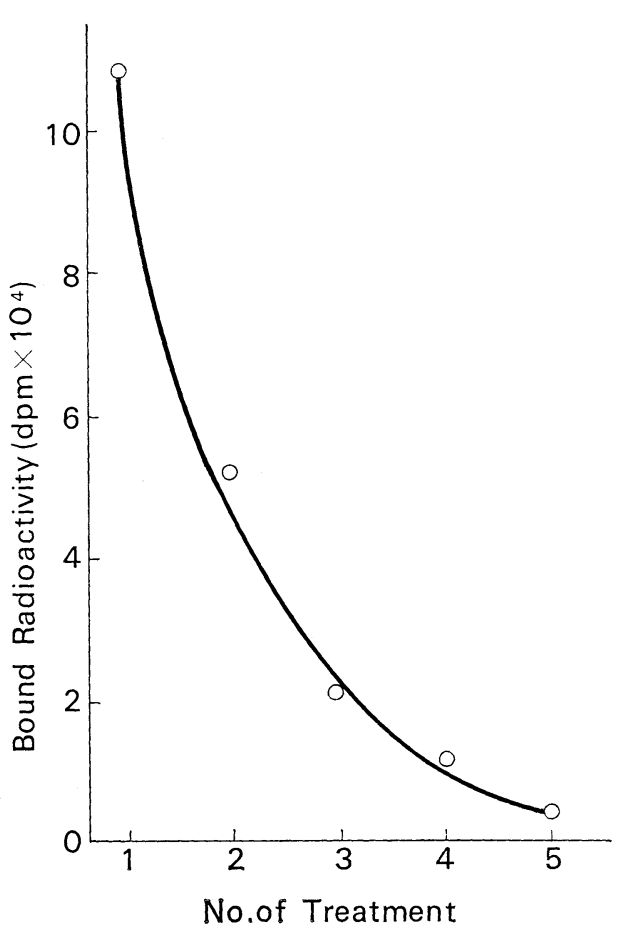

Fig. 3. Effect of multiple treatments with purified liver nuclei on removal of dexamethasone-receptor complex which binds to nuclei. $3.2 \times 10^{5} \mathrm{dpm}$ of dexamethasone-receptor complex was treated with $540 \mu \mathrm{g}$ of liver nuclei (as DNA) 5 times each. Other details of the experimental conditions, see the text. 
component was removed from the cytosol. However, after treatment of the labeled cytosol with DNA-cellulose first, a significant amount of labeled receptor complex was observed and most of the radioactivity in this fraction bound to nuclei on treatments with nuclei. From these results, it has been revealed that the two forms of the dexamethasone-receptor complex exist in the labeled cytosol, one form binds only to nuclei and the other binds to DNA and nuclei. Treatments of labeled cytosol with DNAcellulose followed by treatments with nuclei would enable us to determine the amount of two forms of steroid-receptor complex in labeled cytosols separately.

In the dexamethasone-receptor complex in the liver cytosol, an almost comparable amount of the DNA- and nuclei-bound form was detected (Table 1). In contrast with the dexamethasone-labeled liver cytosol, in cortexolone-labeled liver cytosol and in dihydrotestosterone-labeled prostate cytosol, the DNA-bound radioactivity was almost insignificant. This indicated that the only one form of receptor complex, binding only to nuclei, was present in the latter two cytosols. The total recovery of the bound radioactivity was relatively low in all experiments, and this might be mainly attributed to the receptor complex which bound to cellulose non-specifically was eliminated from incubation mixtures and also to the dissociation of the receptor complex during the incubation periods.

\section{Discussion}

Two forms of the cytoplasmic progesterone-receptor complex in the chick oviduct were separated and purified by Buller et al. (1976) and roles of these two receptor subunits in the action mechanism of steroid hormones were suggested. Following these observations the similar findings were reported on the glucocorticoid-receptor complex in the rat liver and the cultured hepatoma cells (Hamana and Iwai, 1978; Simons, 1977). Two forms of the dexamethasonereceptor complex,--one binds only to nuclei and the other binds to DNA and nuclei in the liver cytosol of rats-were also observed in the present study but the receptor complex which binds to DNA and nuclei was not formed when the liver cytosol was labeled with antiglucocorticoid, cortexolone. From these observations, it is tempting to

Table 1. Binding of steroid-receptor complexes to DNA and nuclei.

\begin{tabular}{lccc}
\hline \multicolumn{1}{c}{ Receptor Complex } & No. of Exp. & DNA-bound & Nuclei-bound \\
\hline \multirow{2}{*}{ Liver-Dexamethasone } & 1 & $(\%)^{*}$ & 38.6 \\
Liver-Cortexolone & 2 & 44.0 & 49.5 \\
Prostate-Dihydrotestosterone & 1 & 0.4 & 77.9 \\
& 2 & 1.9 & 57.0 \\
& 1 & 2.8 & 67.7 \\
\hline
\end{tabular}

Approximately, $180 \mu \mathrm{g}$ DNA-cellulose (as DNA) and $800 \mu \mathrm{g}$ of nuclei (as DNA) were used for each treatment. In the experiments of dexamethasone and cortexolone, nuclei from the liver, and in the experiments of dihydrotestosterone, nuclei from the ventral prostate were used, respectively.

In the dexamethasone experiments, 2.5 and $2.1 \times 10^{5} \mathrm{dpm}$, in the cortexolone experiments, 1.4 and $2.8 \times 10^{5} \mathrm{dpm}$ and in the dihydrotestosterone experiments, 2.6 and $3.4 \times 10^{5} \mathrm{dpm}$ of receptor complexes were used as the starting materials, respectively.

* Percent of radioactivity of the starting materials. DNA-bound radioactivity was corrected for the radioactivity bound to cellulose estimated in parallel incubations performed using DNA-removed DNA-cellulose. 
speculate that the DNA- and nuclei-binding receptor complex plays an indispensable role in the action of glucocorticoids. However, in the rat ventral prostate, only one form of dihydrotestosterone-receptor complex which binds only to nuclei has been detected. According to this result, the hormone-receptor complex which binds to DNA and nuclei would not be required for the action of dihydrotestosterone on the rat ventral prostate. Lack of tissue specificity in the binding of hormone-receptor complex to isolated nuclei has been reported (Buller et al., 1975; Chamness et al., 1973; Ichii, 1975) and the high affinity and saturable binding of dexamethasone-receptor complex to liver nuclei has not been observed in the in vitro binding experiment (Ichii, et al., 1977). On the other hand, the interaction of glucocorticoids and liver cytosol with liver nuclei was postulated to be tissue specific (Milgrom and Atiger, 1975) and a specific high affinity binding of steroid-receptor complexes has also been reported (Kalimi et al., 1973, Buller et al., 1975; Chatkoff and Julian, 1973). The results obtained in experiments of in vitro nuclear binding of steroid-receptor complex have been very conflicting. Therefore, any interpretation of the present data must be made with reservation, in view of the limitations probably inherent in the nuclear binding study of steroid-receptor complex in vitro. However, it would be worthwhile to mention that two forms of steroid-cytoplasmic receptor complex are not the common feature in the action mechanism of steroid hormones.

\section{References}

Buller, R. E., W. T. Schrader and B. W. O'Malley (1975). J. Biol. Chem. 250, 809.

Buller, R. E., R. J. Schwartz, W. T. Schrader and B. W. O'Malley (1976). ibid. 251, 5178.

Buller, R. E., D. O. Toft, W. T. Schrader and B. W. O'Malley (1975). ibid. 250, 801.

Burton, K. (1956). Biochem. J. 62, 315.

Chamness, G. C., A. W. Jenning and W. L. McGuire (1973). Nature 241, 458.

Chatkoff, M. L. and J. A. Julian (1973). Biochem. Biophys. Res. Commun. 51, 1015.

Hamana, K. and K. Iwai (1978). J. Biochem. 83, 279.

Ichii, S. (1975). Endocrinol. Japon. 22, 433.

Ichii, S., N. Murakami and M. Izawa (1977). J. Biochem. 81, 879.

Kalimi, M., M. Beato and P. Feigelson (1973). Biochemistry 12, 3365.

Lowry, O. H., N. J. Rosebrough, A. L. Farr and R. J. Randall (1951). J. Biol. Chem. 193, 265.

Milgrom, E. and M. Atiger (1975). J. Steroid Biochem. 6, 487.

O'Malley, B. W. (1971). Metabolism 20, 981.

O'Malley, B. W., R. J. Schwartz and W. T. Schrder (1976). J. Steroid Biochem. 7, 1151.

Simons, S. S., Jr. (1977). Biochim. Biophys. Acta 496, 339.

Simons, S. S., Jr., H. M. Martinez, R. L. Garcia, J. D. Baxter and G. M. Tomkins (1976). J. Biol. Chem. 251, 334. 